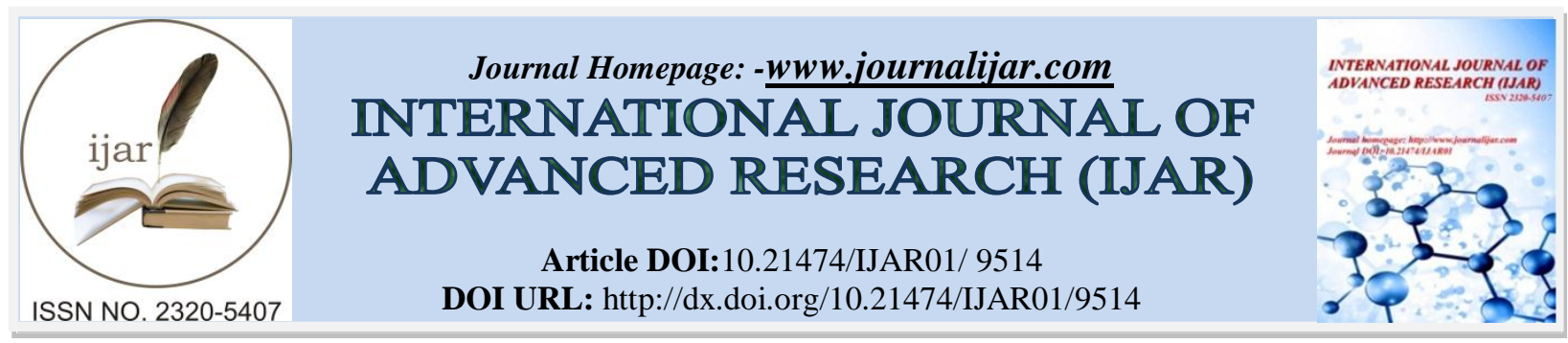

RESEARCH ARTICLE

\title{
BIO-EFFICACY OF ENDOPHYTIC ACTINOMYCETES FOR PLANT GROWTH PROMOTION AND MANAGEMENT OF FUNGAL WILT IN TOMATO (SOLANUM LYCOPERSICUM).
}

Khushboo.

Department of Microbiology, PAU, Ludhiana-141004, Punjab, India.

\section{Manuscript Info}

Manuscript History

Received: 06 June 2019

Final Accepted: 08 July 2019

Published: August 2019

Key words:-

Endophytic actinomycetes, antagonistic, phytopathogenic, plant growth promoting.

\begin{abstract}
The objective of this study was the isolation and screening of endophytic actinomycetes isolates for their antagonistic potential and plant growth promoting activities. A total of 60 isolates were recovered from root, stem and leaf tissue of 30 tomato plants. Studies on plant growth promoting activities revealed that 44 showed abilities to produce indole acetic acid, 18 produced siderophores, 34 ammonia and 16 were observed to solubilize phosphate. In addition, production of hydrolytic enzymes such as chitinase, amylase and protease was demonstrated by these isolates. The efficacy of all endophytic actinomycetes was tested against Rhizoctonia solani pathogen in tomato, among 60 isolates obtained; seven endophytic actinomycetes were antagonistic to Rhizoctonia solani in vitro. Among them, potential isolate actinomycete was promising in vivo.
\end{abstract}

Copy Right, IJAR, 2019,. All rights reserved.

\section{Introduction:-}

Tomato (Solanum lycopersicum) is the most popular and agriculturally important commercial vegetable crop grown throughout the world. It is rich in vitamins A, B, C and has high lycopene content. Being versatile for culinary purposes, it is also one of the most commonly grown vegetable in the kitchen garden [1]. In India, it occupies an area of 801 thousand ha with a production of 22337 million tonnes [2]. Several diseases and disorders can influence tomato during the growing period. Loss of crop yield is a major concern in agriculture worldwide due to phytopathogens, especially fungi. Among the various diseases affecting the crop, Rhizoctonia solani is one of the most calamitous, soil-borne pathogen causes substantial loss to tomato crop [3].This pathogen can survive in soil within diseased plant material as mycelia or sclerotia during unfavorable environmental conditions for several years [4] causing root and crown rot. The chemical fungicides are used to control diseased crops. However, continuous use of fungicides has resulted in increased fungicide resistance, environmental pollution, detrimental effects on beneficial non-target organisms as well as severe effects on human life [5]. In recent years, natural or biological control has emphasised by providing an environment friendly, long lasting, inexpensive, safe alternate for the control of plant diseases [6]. The microorganisms are attractive source of natural compounds for pharmaceutical and agricultural industries. Therefore, the search has accelerated to screen microorganisms to find bioactive molecules (secondary metabolites and enzymes) antagonistic to plant pathogens [7]. Endophytes are microorganisms, proficiently and firmly colonize different plant tissues, from roots to all aerial parts, have been recognized, and has pivotal importance in agriculture [8] therefore, use of endophytic actinomycetes as biocontrol agent of soil borne diseases is of interest through their ability to colonize healthy plant tissues and produce antibiotics in situ [9]. Sreeja and Gopal [1] observed that Streptomyces thermodiastaticus an endophytic actinomycete isolated from tomato

Corresponding Author:-Khushboo

Address:-Department of Microbiology, PAU, Ludhiana-141004, Punjab, India. 
plants showed (44.63\%) antimicrobial activity against Ralstonia solanacearum causes wilt in tomato. They are also known for their ability to promote plant growth by producing plant growth hormone such as indole acetic acid also help in nitrogen fixation, phosphate solubilisation and siderophore production [10]. In this context, the present study was taken up to know more about the bioefficacy of endophytic actinomycetes on plant growth promotion and management of fungal wilt in tomato.

\section{Material and methods:-}

\section{Collection of samples and isolation of endophytic actinomycetes}

A total of 60 endophytic actinomycetes isolates were isolated from healthy tomato plants. Local cultivars of both young (less than two weeks) and old plants (more than two weeks) were obtained from different locations and fungal culture of Rhizocotnia solanii was procured from the department of Microbiology, Punjab agricultural university, ludhiana, (India).

\section{Determination of plant growth promoting activities Phosphate Solubilization}

Qualitative phosphate solubilization activity of endophytic actinomycetes isolates were analyzed on NBRI-BPB agar medium. Actinomycetes cultures were inoculated on plates containing NBRI-BPB medium and incubated at $28^{\circ} \mathrm{C}$ for 7 days and the colonies forming yellow halo zone were considered as phosphate solubilizers and were selected allowed to grow for 7 days in broth was carried out using Erlenmeyer flasks (250ml) containing $50 \mathrm{ml}$ of Pikovskaya medium grown for 7 days for quantitative estimation of $\mathrm{P}$ - solubilization using a standard method done by Olsen and Sommers [11].

\section{Indole acetic acid (IAA) production}

The production of IAA by endophytic actinomycetes isolates were estimated according to Gordon and Weber [12] with some modifications. Endophytic actinomycetes were inoculated in $100 \mathrm{ml}$ Erlenmeyer flasks containing yeast malt extract broth for 10 days in a rotary shaker at $200 \mathrm{rpm}, 28^{\circ} \mathrm{C}$ for 7 days. The $10 \mathrm{ml}$ of grown culture was taken in eppendorff tubes and centrifuged at $10,000 \mathrm{rpm}$ for 20 minutes and $1 \mathrm{ml}$ supernatant was mixed with $2 \mathrm{ml}$ Salkowski's reagent and incubated for $30 \mathrm{~min}$ at room temperature. Development of a pink color indicated IAA production.

\section{Ammonia production}

The endophytic actinomycetes isolates were tested for the production of ammonia using the method described by Cappucino and Sherman [13]. In this method $20 \mu \mathrm{l}$ of seed culture was propagated in $10 \mathrm{ml}$ of peptone water and incubated at $28^{\circ} \mathrm{C}$ with shaking at $120 \mathrm{rpm}$ for $10 \mathrm{~d}$. Subsequently, $0.5 \mathrm{ml}$ of Nesseler's reagent was added to the culture and the development of brown to yellow color indicated a positive test for ammonia production. The absorbance was measured at $530 \mathrm{~nm}$ using a Thermo scientific (Multiskan GO) spectrophotometer, compared with the standard curve of $\left(\mathrm{NH}_{4}\right)_{2} \mathrm{SO}_{4}$ and expressed in $\mathrm{mg} / \mathrm{ml}$.

\section{Siderophore production}

Siderophore production of the endophytic actinomycetes was determined by the method of Schwyn and Neilands [14]. A loop full of culture was inoculated on Chrome azurol S (CAS) agar medium and incubated at $28 \pm 2{ }^{\circ} \mathrm{C}$ for 5 days. The colony with a halo zone of yellow-orange color was considered positive for siderophore production. The positive isolates were cultured in yeast malt extract broth and incubated at $28^{\circ} \mathrm{C}$ for 10 days with shaking at $120 \mathrm{rpm}$ for 10 days. Catechol-type siderophores were estimated by Arnow's method [15] and hydroxamate siderophores were determined using the Csaky test [16].

\section{Chitinase activity}

The test for chitinase production was performed by the procedure described by (Taechowisan and Lumyong [17], Tang-um and Niamsup [18]. Colloidal chitin was prepared from the chitin by the modified method of Hsu and Lockwood [19]. The clear halo zone measured on colloidal chitin agar medium showed positive chitinase activity. For the quantitative estimation of chitinase activity $0.6 \%$ and $1 \%$ colloidal chitin concentration was used. Colloidal chitin broth was used as a production medium with $\mathrm{pH} 7$ and incubated at $28^{\circ} \mathrm{C}$ in the incubator shaker at $150-160$ rev min-1 for 7 days. Spores were inoculated to a concentration of $10^{5} \mathrm{ml}^{-1}$. Chitinase activity in the supernatant was determined by the procedure of Taechowisan and Lumyong [17], Tang-um and Niamsup [18]. The amount of Nacetyl glucosamine (GlcNAc) released in the supernatant was spectrophotometrically measured by the method of 
Somogyi-Nelson [20] on the 520-nm absorbance. One unit (U) of chitinase activity was defined as the amount of enzyme required to produce $1 \mathrm{~mol}$ of reducing sugar per min. under the conditions of the experiment.

\section{In vitro antagonistic bioassay}

The endophytic actinomycetes isolates were evaluated for their antagonistic activity against phytopathogenic fungus Rhizoctonia solani by dual-culture in vitro assay. Colony growth inhibition (\%) was calculated by using the formula: $\mathrm{C}-\mathrm{T} / \mathrm{C} \mathrm{x} 100$, where $\mathrm{C}$ is the colony growth of pathogen in control and $\mathrm{T}$ is the colony growth of pathogen in dual culture.

\section{Green house experiment}

The most potent endophytic actinomycete isolate Streptomyces sp. was grown on starch caisein nutrient agar (SCNA) broth at $28^{\circ} \mathrm{C}$ for seven days with continuous shaking at $150 \mathrm{rpm}$. The cells were centrifuged at $10,000 \mathrm{rpm}$ for $15 \mathrm{~min}$ and the pellets diluted with distilled water to yield a final concentration of $10^{6} \mathrm{CFU} / \mathrm{ml}$. The endophytic actinomycete suspension was used to treat targeted plants under green house conditions. Soil was taken from field and sterilized by autoclaving at $121^{\circ} \mathrm{C}$ for $1 \mathrm{hr}$ for 3 consecutive days. Tomato seeds (Variety-Punjab sartaj) were grown in pots, using completely randomized block design (CRD) with 4 treatments and 3 replications each. Five seeds were sown per pot containing sterile soil. The treatments were $\left(\mathrm{T}_{0}\right)$ Control with sterile soil only, $\left(\mathrm{T}_{1}\right)$ Seeds treated with fungal spore suspension(Rhizocotnia solanii), $\left(\mathrm{T}_{2}\right)$ Seeds treated with filtrate of potential actinomycete isolate (TR60) + fungal spore suspension and $\left(\mathrm{T}_{3}\right)$ Seeds treated with filtrate of with potential actinomycete isolate. Observations on per cent wilt incidence, days to flowering, number of fruits per plant, per fruit weight and yield per plant were recorded and statistically analysed using ANOVA.

\section{Molecular characterization and phylogenetic analysis of antagonistic endophytic actinomycetes}

Total DNA of endophytic actinomycetes isolate from cells, processed for genomic DNA extraction. The fragment of 16S rDNA gene was amplified by PCR from the above isolated DNA, a single discrete PCR amplicon band of 1500 bp was observed when resolved on agarose. Forward and reverse DNA sequencing reaction of PCR amplicon was carried out with 8F and 1492R primers using BDT v3.1 Cycle sequencing kit on ABI 3730xl Genetic Analyzer. Consensus sequence of 1366bp 16S rDNA gene was generated from forward and reverse sequence data using aligner software. The $16 \mathrm{~S}$ rDNA gene sequence was used to carry out BLAST with the nr data base of NCBI gen bank database. Based on maximum identity score first ten sequences were selected and aligned using multiple alignment software program Clustal W. Distance matrix was generated using RDP database and the phylogenetic tree was constructed using MEGA 4.

\section{Results and Discussion:-}

\section{Isolation and identification of endophytic actinomycetes}

A total of 60 endophytic actinomycetes were isolated from root, stem and leaf tissues of 30 healthy tomato plants, and identified based on their morphological and biochemical characteristics. Out of 60 isolates, 39 belonged Streptomyces sp. followed by 7 Nocardia sp., 5 Micromonospora sp., 6 Microbisspora sp. and 3 Actinopolyspora sp. Results were found in agreement with previous findings of endophytic actinomycetes isolation from, banana, chilli and Saccharum officinarum roots, leaf and stem tissues [21, 22, 23].

\section{Plant growth promoting traits of endophytic actinomycetes.}

Phosphate solubilization and IAA production Among the 60 endophytic actinomycetes isolates, 16 (26.67\%) were able to solubilize inorganic phosphate and were identified as potential phosphate solubilizing isolates based on a clear halo zone around the colony on NBRI-BPB agar medium. Quantitative estimation of phosphate solubilization by the endophytic actinomycetes ranged from $4.2 \pm 0,02-32.42 \pm 0.2 \mathrm{mg} / \mathrm{ml}$ (Table 1). Forty-four endophytic actinomycetes $(73.33 \%)$ were positive for IAA production; quantitative range of IAA production was found from $2.38 \pm 0.21$ to $124.37 \pm 0.26 \mu \mathrm{g} / \mathrm{ml}$ (Table 1) with the highest by Streptomyces sp. TR60.

\section{Ammonia and siderophore production by endophytic actinomycetes.}

Thirty-four isolates were positive for the production of ammonia at levels ranging from $1.84 \pm 0.001$ to $29.37 \pm 0.06$ $\mathrm{mg} / \mathrm{ml}$. Isolate Streptomyces $\mathrm{sp}$. TS14 produced the maximum amount of ammonia $(29.37 \pm 0.06 \mathrm{mg} / \mathrm{ml})$ followed by Streptomyces sp TR60 $(27.05 \pm 0.19 \mathrm{mg} / \mathrm{ml})$. Siderophore production was detected in 18 (30\%) isolates on CAS agar media, forming clear orange halo zone around the colonies. The seven isolates produced catachol type siderophore (at levels ranging from $2.8 \pm 0.2$ to $92.50 \pm 0.2 \mu \mathrm{g} / \mathrm{ml}$ ), whereas, 16 isolates produced hydroxamatetype 
siderophore (range from $3.9 \pm 0.2$ to $134.50 \pm 0.09 \mu \mathrm{g} / \mathrm{ml}$ ). Isolate Streptomyces sp. TR60 produced greatest amount siderophore (Table 1).

\section{Chitinase production.}

On the basis of maximum antifungal activity as well as hydrolytic enzymes production, the endophytic actinomycete isolate Streptomyces sp. TR60 was selected for qualitative production of chitinase enzyme by plate agar assay. A clear zone surrounding the actinomycetes colony was observed, indicating that Streptomyces sp. TR60 produced chitinase. Maximum chitinase activity was observed on 4 th day $0.061 \mathrm{U} / \mathrm{ml}$ at $0.6 \%$ colloidal chitin concentration. With $1 \%$ colloidal chitin substrate concentration, the maximum activity was observed $0.059 \mathrm{U} / \mathrm{ml}$ on 4 th day (Fig 1 ) as compared to standard (Fig 1.2). Similar observations were reported by [26, 27] during production of chitinase from $S$. marcescens and S. lividans, where by enzyme production was observed at exponential stage i.e. $84 \mathrm{~h}$.

\section{In vitro antagonistic activity of endophytic actinomycete isolates against phytopathogenic fungus}

Out of sixty isolates, 7 isolates (11.67\%) were displaying antagonistic activity against Rhizoctonia solani. The antagonistic activity of endophytic actinomycete isolates against phytopathogenic fungus was observed to fall in a range of $4.60 \pm 0.03 \%$ to $39.85 \pm 0.36 \%$. It was observed that root endophytes were better antagonistic agents as compared to stem and leaf isolates. Isolate TR60 showed the maximum percent inhibition against Rhizoctonia solani (39.85 $\pm 0.36 \%)$ when compared with control. Passari et al [28] recovered forty-two endophytic actinomycetes from medicinal plants were evaluated for their antagonistic potential and plant growth-promoting abilities. Twenty-two isolates which showed the inhibitory activity against at least one pathogen were subsequently tested for their plantgrowth promoting activities and were compared genotypically using DNA based fingerprinting.

\section{Scanning electron microscopy (SEM)}

Scanning electron microscopy was employed to evaluate the effects of Streptomyces sp TR60 on the fungal cell walls of Rhizoctonia solani. The co-culture containing $R$. solani and endophytic actinomycete isolate TR60 as well as $R$. solani culture alone as a control was selected for experiment. Results obtained showed that control appeared sectored regular vegetative cells along with large roughly spherical spores (Fig 2A) whereas fungal colony cocultured with TR60 showed aberrant vegetative cell structure of the hyphae. Further, the fungal hyphae appeared like flattened ribbons having several pits at the poles (Fig 2B) as well as presence of bulbous structures at the edges of the inhibited fungal colonies on the PDA plates was evident (Fig3B). Our results are in conformity with several studies carried out by other investigators. Rawlinson et al [29] observed that the bacterial cells examined using SEM, were totally deformed and exhibited severe destruction. The surfaces of the bacterial cells were damaged and had become rough and swollen, but unlysed.

In vivo plant growth activity of tomato seedlings under pot culture conditions.

The most potent isolate Streptomyces sp. TR60 identified by 16S rRNA gene sequencing as strains of Streptomyces fulvissimus (Table 3) was used for in vivo greenhouse experiment on tomato. Inoculation of with Streptomyces TR60, showed a significant $(\mathrm{p}<0.05)$ increase in yield parameters such as days to flowering, root and shoot length treated with the endophytic actinomycetes were superior in performance when compared to the control (Table 2). In the present study the plants treated with Streptomyces fulvissimus (TR60) isolate recorded the minimum number of days (31.67) for flowering, followed by seeds treated with filtrate of potential actinomycete isolate and fungal spore suspension (36.66) as compared to absolute control.

Wilt incidence seeds treated with only fungus was recorded of $92.30 \%$ that reduced to $53.62 \%$ seeds treated with Streptomyces fulvissimus + fungus (table 2). Hence, it is concluded from the study that the endophytic actinomycetes, Streptomyces fulvissimus from tomato showed superior performance among the all isolates in plant growth promotion as well as in the management of fungal wilt in tomato. This promising endophytic actinomycete has a potential to be developed as a biocontrol agent for the management of fungal wilt in tomato. 
Table 1:-Relative production of IAA, P-solubilization, Ammonia and siderophores by endophytic actinomycete from Solanum lycopersicum (tomato)

\begin{tabular}{|c|c|c|c|c|c|}
\hline \multirow[t]{2}{*}{ Isolates } & \multirow[t]{2}{*}{ IAA $(\mu \mathrm{g} / \mathrm{ml})$} & \multirow{2}{*}{$\begin{array}{l}\text { Phosphate } \\
\text { solubilization } \\
\text { (mg/100ml) }\end{array}$} & \multirow{2}{*}{$\begin{array}{l}\text { Ammonia } \\
(\mathrm{mg} / \mathrm{ml})\end{array}$} & \multicolumn{2}{|l|}{ Siderophore } \\
\hline & & & & $\begin{array}{l}\text { Hydroxamate } \\
(\mu \mathrm{g} / \mathrm{ml})\end{array}$ & Catechol $(\mu \mathrm{g} / \mathrm{ml})$ \\
\hline TR1 & $8.69 \pm 0.12$ & - & $5.49 \pm 0.01$ & - & - \\
\hline TR2 & $6.4 \pm 0.06$ & $6.5 \pm 0.2$ & $3.66 \pm 0.06$ & - & - \\
\hline TL3 & $51.89 \pm 0.33$ & $11.6 \pm 0.03$ & $11.66 \pm 0.005$ & $92.1 \pm 0.2$ & $20.2 \pm 0.5$ \\
\hline TS4 & $29.07 \pm 0.07$ & $17.1 \pm 0.16$ & $6.42 \pm 0.003$ & - & - \\
\hline TR5 & $22.12 \pm 0.32$ & $16.5 \pm 0.02$ & - & - & $16.2 \pm 0.1$ \\
\hline TR6 & $5.62 \pm 0.22$ & - & - & - & - \\
\hline TL7 & $18.07 \pm 0.32$ & - & $19.43 \pm 0.006$ & $3.9 \pm 0.2$ & - \\
\hline TL8 & $13.43 \pm 0.027$ & - & $7.99 \pm 0.013$ & - & - \\
\hline TL10 & $2.38 \pm 0.21$ & $4.4 \pm 0.03$ & $26.30 \pm 0.041$ & - & - \\
\hline TL11 & $7.6 \pm 0.04$ & $14.9 \pm 0.04$ & $20.47 \pm 0.003$ & - & - \\
\hline TR12 & $9.16 \pm 0.19$ & $11 \pm 0.12$ & $5.38 \pm 0.005$ & - & - \\
\hline TS13 & $3.68 \pm 0.25$ & - & - & - & - \\
\hline TS14 & $29.2 \pm 0.28$ & - & $29.37 \pm 0.06$ & $38.2 \pm 0.3$ & - \\
\hline TR15 & $10.86 \pm 0.14$ & $10.6 \pm 0.41$ & - & $50.7 \pm 0.2$ & $42.1 \pm 0.2$ \\
\hline TR16 & $41.94 \pm 0.35$ & - & $11.4 \pm 0.005$ & - & - \\
\hline TL18 & $16.52 \pm 0.25$ & $12.5 \pm 0.02$ & $9.65 \pm 0.005$ & $70.2 \pm 0.3$ & $25.4 \pm 0.2$ \\
\hline TL19 & $5.88 \pm 0.34$ & - & $8.15 \pm 0.27$ & - & - \\
\hline TR20 & $42.89 \pm 0.21$ & $9.4 \pm 0.32$ & $2.52 \pm 0.006$ & - & - \\
\hline TL21 & $7.51 \pm 0.17$ & $5.8 \pm 0.01$ & $23.91 \pm 0.03$ & $26.4 \pm 0.4$ & - \\
\hline TR22 & $54.24 \pm 0.23$ & - & $19.73 \pm 0.03$ & - & - \\
\hline TR23 & $9.94 \pm 0.54$ & - & $3.95 \pm 0.003$ & $38 \pm 0.3$ & - \\
\hline TL24 & $7.43 \pm 0.08$ & - & $4.73 \pm 0.09$ & - & - \\
\hline TR25 & $3.33 \pm 0.11$ & - & $1.84 \pm 0.001$ & - & - \\
\hline TR26 & $24.23 \pm 0.40$ & - & $6.35 \pm 0.003$ & $16.8 \pm 0.2$ & - \\
\hline TS28 & $28.96 \pm 0.20$ & - & - & - & - \\
\hline TL29 & $5.4 \pm 0.09$ & - & $21.75 \pm 0.005$ & - & - \\
\hline TL30 & $11.55 \pm 0.13$ & - & $8.44 \pm 0.01$ & - & - \\
\hline TR31 & $2.45 \pm 0.19$ & - & $18.38 \pm 0.03$ & - & - \\
\hline TR32 & $4.5 \pm 0.19$ & - & $21.60 \pm 0.026$ & - & - \\
\hline TL33 & $51.5 \pm 0.59$ & $13.8 \pm 0.01$ & $8.44 \pm 0.01$ & $46.2 \pm 0.2$ & - \\
\hline TR34 & $56.66 \pm 0.71$ & - & $18.38 \pm 0.03$ & - & - \\
\hline TL35 & $40.73 \pm 0.26$ & $4.2 \pm 0.02$ & $21.60 \pm 0.02$ & - & - \\
\hline TR36 & $2.65 \pm 0.12$ & - & $12.10 \pm 0.01$ & $5.1 \pm 0.5$ & - \\
\hline TR39 & $27.81 \pm 0.4$ & - & $2.31 \pm 0.008$ & $15.4 \pm 0.1$ & - \\
\hline TL38 & - & - & - & $12.6 \pm 0.1$ & - \\
\hline TR43 & $60.31 \pm 0.07$ & - & - & - & - \\
\hline TR40 & - & - & - & $11.2 \pm 0.1$ & - \\
\hline TL45 & $22.69 \pm 0.27$ & - & $3.06 \pm 0.006$ & - & - \\
\hline TS46 & $10.69 \pm 0.27$ & - & - & $52.4 \pm 0.2$ & - \\
\hline TR49 & $51.73 \pm 0.34$ & - & - & - & - \\
\hline TS50 & $41.93 \pm 0.38$ & $20.2 \pm 0.15$ & $19.05 \pm 0.01$ & - & $9.3 \pm 0.07$ \\
\hline TR52 & $35.83 \pm 0.36$ & - & - & - & - \\
\hline TL56 & $53.8 \pm 0.25$ & - & $17.71 \pm 0.02$ & $15.4 \pm 0.09$ & $2.8 \pm 0.2$ \\
\hline TR58 & $6.02 \pm 0.37$ & $8.2 \pm 0.1$ & $18.76 \pm 0.003$ & - & - \\
\hline TS59 & $10.54 \pm 0.040$ & - & - & - & - \\
\hline TR60 & $124.37 \pm 0.26$ & $32.42 \pm 0.2$ & $27.05 \pm 0.19$ & $134.5 \pm 0.09$ & $92.5 \pm 0.2$ \\
\hline
\end{tabular}




\begin{tabular}{|l|l|l|l|l|l|}
\hline CD@5\% & 0.90 & 0.33 & 0.17 & 0.22 & 0.53 \\
\hline
\end{tabular}

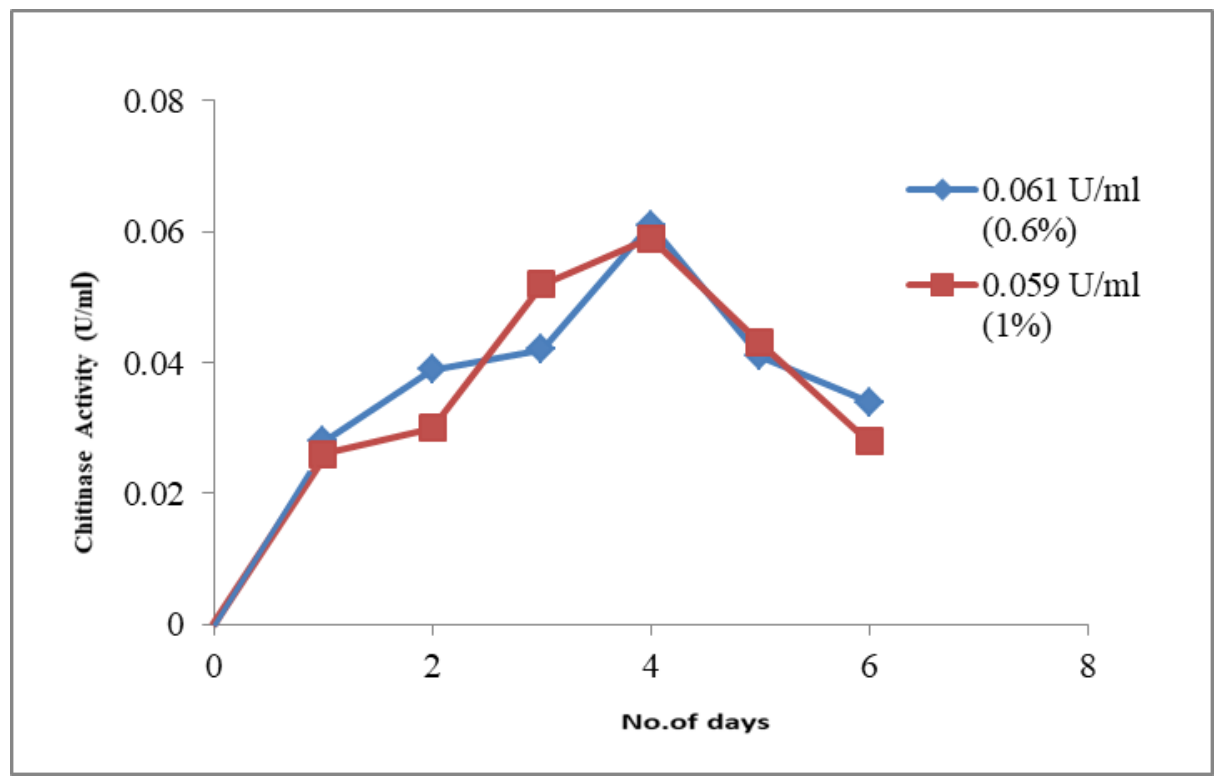

Fig 1:-Quantitative production of chitinase by TR60 isolate

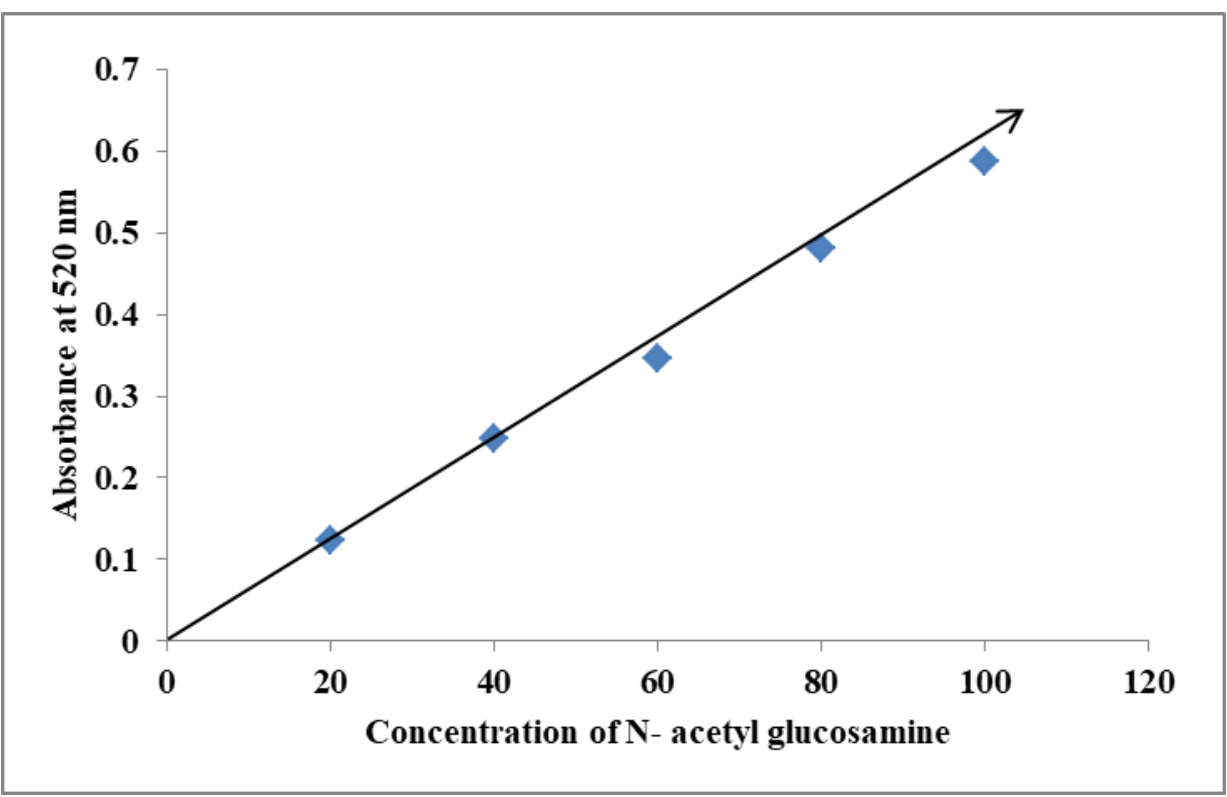

Fig1.2:-Standard curve of $\mathrm{N}$-acetyl glucosamine 


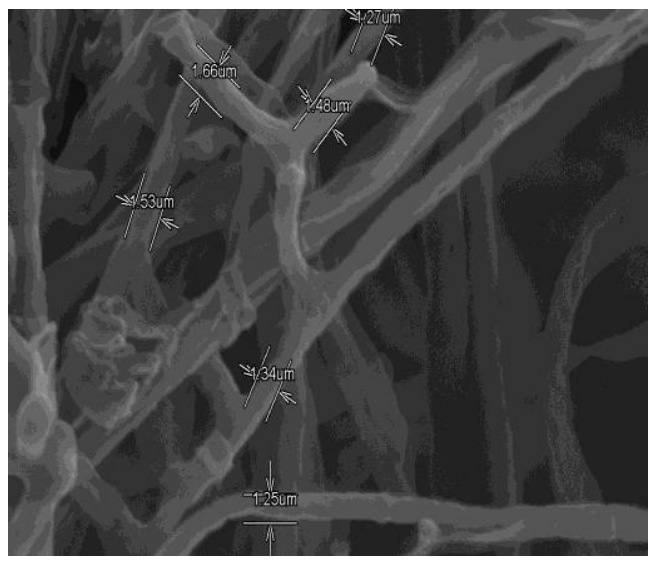

Fig 2:- (A) Rhizocotonia solani from pure culture

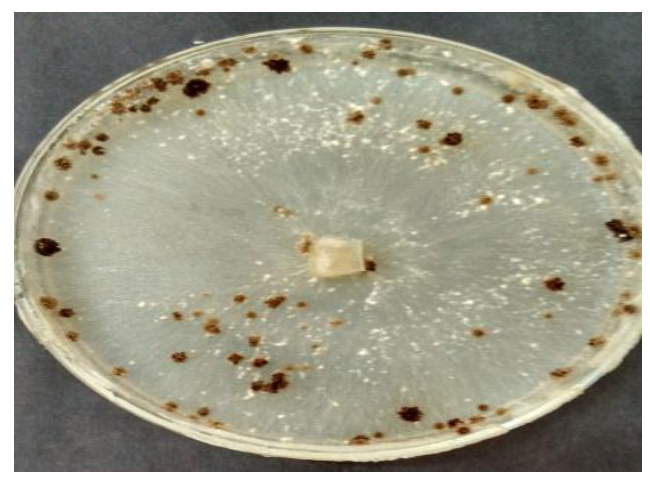

Fig 3:- (A) Rhizoctonia solani

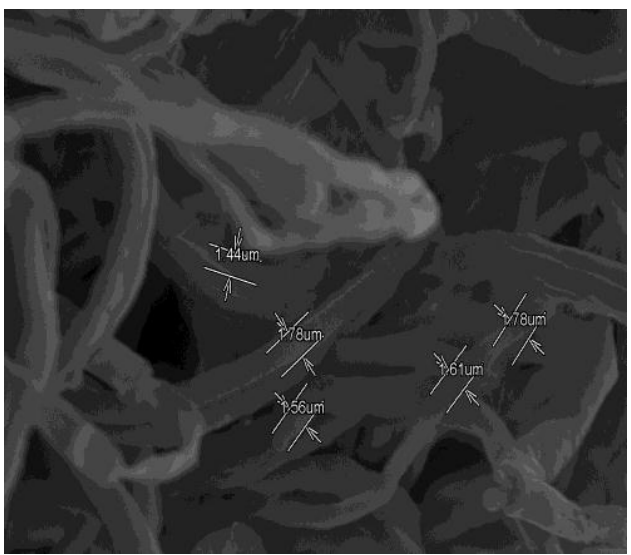

(B) co-cultured Rhizocotonia solani with Streptomyces sp. (TR60)

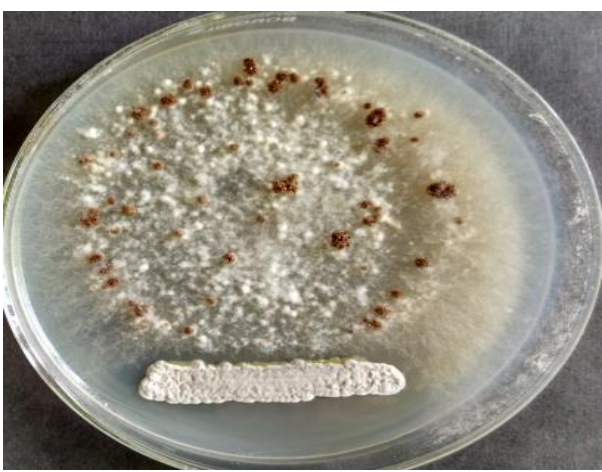

(B) Rhizoctonia solani + TR60

Table 2:-Effect of various treatments on fungal wilt in tomato

\begin{tabular}{|c|c|c|c|c|c|c|c|c|c|c|c|}
\hline \multirow[t]{2}{*}{ Treatment } & \multirow{2}{*}{$\begin{array}{l}\text { Wilt } \\
\text { incidence } \\
(\%)\end{array}$} & \multirow{2}{*}{$\begin{array}{l}\text { Days to } \\
\text { flowering }\end{array}$} & \multicolumn{3}{|c|}{ Number of shoots } & \multicolumn{3}{|c|}{ shoot length $(\mathrm{cm})$} & \multicolumn{3}{|c|}{ Root length (cm) } \\
\hline & & & $\begin{array}{l}\text { 30 } \\
\text { DAS }\end{array}$ & $\begin{array}{l}\text { 60 } \\
\text { DAS }\end{array}$ & $\begin{array}{l}90 \\
\text { DAS }\end{array}$ & $\begin{array}{l}\text { 30 } \\
\text { DAS }\end{array}$ & $\begin{array}{l}\text { 60 } \\
\text { DAS }\end{array}$ & $\begin{array}{l}90 \\
\text { DAS }\end{array}$ & $\begin{array}{l}30 \\
\text { DAS }\end{array}$ & $\begin{array}{l}\text { 60 } \\
\text { DAS }\end{array}$ & $\begin{array}{l}90 \\
\text { DAS }\end{array}$ \\
\hline T0 & - & 40.67 & 8.33 & 10.66 & 14.55 & 8.57 & 10.67 & 21.71 & 5.55 & 6.21 & 12.06 \\
\hline T1 & 92.30 & 43.33 & 7.66 & 7.15 & 5.89 & 7.83 & 8.33 & 10.21 & 4.51 & 4.68 & 4.60 \\
\hline $\mathrm{T} 2$ & 53.62 & 36.66 & 11.33 & 12.11 & 18.55 & 11.45 & 15.21 & 19.60 & 6.75 & 6.35 & 10.23 \\
\hline T3 & - & 31.67 & 12.33 & 14.33 & 27.43 & 11.78 & 18.85 & 23.97 & 6.55 & 6.11 & 12.80 \\
\hline $\mathrm{CD}$ at $5 \%$ & & 0.87 & 1.49 & 0.79 & 0.35 & 1.53 & 1.25 & 2.47 & NS & 0.93 & 0.92 \\
\hline
\end{tabular}

T0 - Absolute Control (no pathogen and no actionmycete)

$\mathrm{T} 1$ - Control (pathogen only)

T2 - Seeds treated with filtrate of potential actinomycete isolate + fungal spore suspension

T3 - Seeds treated with filtrate of potential actinomycete isolate TR60 
Table 3:-Sequence producing significant alignments (TR60)

\begin{tabular}{|c|c|c|c|c|c|c|}
\hline Description & $\begin{array}{l}\text { Max } \\
\text { score }\end{array}$ & $\begin{array}{l}\text { Total } \\
\text { score }\end{array}$ & $\begin{array}{l}\text { Query } \\
\text { cover }\end{array}$ & $\begin{array}{c}E \\
\text { value }\end{array}$ & Ident & Accession \\
\hline$\square$ Streptomyces fulvissimus strain FHM275 16S ribosomal RNA gene, partial sequence & 1146 & 1146 & $99 \%$ & 0.0 & $99 \%$ & $\underline{\mathrm{KM} 438035.1}$ \\
\hline$\square$ Uncultured bacterium clone MONS IW0306 1116 S ribosomal RNA gene, partial sequence & 1118 & 1118 & $98 \%$ & 0.0 & $99 \%$ & FJ432349.1 \\
\hline$\square$ Variovorax sp. strain MAK8 $16 \mathrm{~S}$ ribosomal RNA gene, partial sequence & 1116 & 1116 & $98 \%$ & 0.0 & $99 \%$ & $\underline{K X 665557.1}$ \\
\hline$\square$ Variovorax boronicumulans partial 16S rRNA gene, isolate 1011MAR4D42.1 & 1116 & 1116 & $98 \%$ & 0.0 & $99 \%$ & $\underline{\text { LN867144.1 }}$ \\
\hline$\square$ Variovorax sp. i25s gene for $16 \mathrm{~S}$ rRNA, partial sequence & 1116 & 1116 & $98 \%$ & 0.0 & $99 \%$ & $\underline{\text { AB974279.1 }}$ \\
\hline$\square$ Uncultured bacterium clone HJ3E05 16S ribosomal RNA gene, partial sequence & 1116 & 1116 & $98 \%$ & 0.0 & $99 \%$ & $\underline{\mathrm{JX644348.1}}$ \\
\hline$\square \underline{\text { Variovorax sp. SMX332 partial 16S rRNA gene, strain SMX332 }}$ & 1116 & 1116 & $98 \%$ & 0.0 & $99 \%$ & $\underline{\mathrm{HF} 571534.1}$ \\
\hline$\square \underline{\text { Variovorax sp. LY1 16S ribosomal RNA gene, partial sequence }}$ & 1116 & 1116 & $98 \%$ & 0.0 & $99 \%$ & $\underline{\mathrm{J} Q 360172.1}$ \\
\hline$\square$ Variovorax sp. CRF3-Va-1 16S ribosomal RNA gene, partial sequence & 1116 & 1116 & $98 \%$ & 0.0 & $99 \%$ & $\underline{\mathrm{JQ} 010855.1}$ \\
\hline$\square \underline{\text { Uncultured Variovorax sp. partial } 16 \mathrm{~S} \text { rRNA gene, clone } \mathrm{H} 319-9}$ & 1116 & 1116 & $98 \%$ & 0.0 & $99 \%$ & $\underline{\text { HE} 585190.1}$ \\
\hline$\square$ Uncultured Comamonadaceae bacterium clone G-19 16S ribosomal RNA gene, partial sequence & 1116 & 1116 & $98 \%$ & 0.0 & $99 \%$ & $\underline{\mathrm{J} F 703396.1}$ \\
\hline$\square$ Uncultured bacterium clone POME T37 B18 16S ribosomal RNA gene, partial sequence & 1116 & 1116 & $98 \%$ & 0.0 & $99 \%$ & $\underline{\mathrm{HM} 440296.1}$ \\
\hline
\end{tabular}

\section{References}

1. Sreeja, S.J. and Gopal K. S. (2013) Bio-efficacy of endophytic actinomycetes for plant growth promotion and management of bacterial wilt in tomato. Pest Management in Horticultural Ecosystems 19 (1):63-66.

2. National Sample Survey Office (NSSO), Ministry of Statistics and Programme Implementation, government of India (2016-17).

3. Youssef, S.A., Kamel, A.T., Ghada, A. A. (2016) Evaluation of Trichoderma harzianum and Serratia proteamaculans effect on disease suppression, stimulation of ROS-scavenging enzymes and improving tomato growth infected by Rhizoctonia solani. Journal of Biological Control 100: 79-86.

4. Parissa Taheri and Saeed Tarighi (2012) The Role of Pathogenesis-Related Proteins in the Tomato-Rhizoctonia solani Interaction. Journal of Botany pp 1-6.

5. Romanazzi, G., Smilanick, J.,Feliziani, E., Droby, S. (2016) Integrated management of postharvest gray mold on fruit crops. Postharvest Biology and Technology 113:69-76.

6. Kachhawa D (2017) Microorganisms as a biopesticides. Journal of Entomology and Zoology Studies 2017; 5(3): 468-473.

7. Gangwar, M., Kaur, N., Saini, P. and Kalia, A. (2015) The diversity, plant growth promoting and anti-microbial activities of endophytic actinomycetes isolated from Emblica officinalis Gaertn. International Journal of Advance Research 3: 1062-71.

8. Vurukonda, S.S., Prasad K., Davide G. and Emilio, S. (2018) Plant Growth Promoting and Biocontrol Activity of Streptomyces spp. as Endophytes. International Journal of Molicular Science 19: 952.

9. Gangwar, M., Dogra, S., Gupta, U.P., Kharwar, R.N. (2014) Diversity and biopotential of endophytic actinomycetes from three medicinal plants in India. African Journal of Microbiology 8(2): 184-191.

10. Passari, A. K., Mishra, V. K., Singh, G., Singh, P., Kumar, B., Gupta, V. K., Sarma, R. K., Donovan, A. O. and Singh, B. P. (2017) Insights into the functionality of endophytic actinobacteria with a focus on their biosynthetic potential and secondary metabolites production. Science Reports 7:1-17.

11. Olsen, S. and Sommers, L.E. (1982) Phosphorus In: Methods of Soil Analysis. Part 2: Chemical and Microbiological Properties. American Society of Agronomy pp 403-427.

12. Gordon, S.A.,Weber, R.P. (1951) Colorimetric estimation of indole acetic acid. Journal of Plant Physiology 26: 192-195.

13. Cappucino, J.C., Sherman N. (1992) Microbiology: a laboratory manual. New York, Benjamin: Cummings Publishing Company; p. 125-179. 
14. Schwyn, B., Neilands, J,B. (1987) Universal chemical assay for the detection and determination of siderophores. Anals of Biochemistry 160: 47-56.

15. Arnow, L.E. (1937) Calorimetric estimation of components of 3, 4 dihydroxy phenylalanine tyrosine mixtures. Journal of Biological Chemistry 118:531-535.

16. Csaky, T.Z. (1948) On the estimation of bound hydroxylamine in biological materials. Acta Chemistry Scand 2: 450-54.

17. Taechowisan, T., Peberdy, J.F. and Lumyong, S. (2003) Chitinase production by endophytic Streptomyces aureofaciens CMUAc130 and its antagonism against phytopathogenic fungi. Annals of Microbiology 53: 44761.

18. Tang-um, J. and Niamsup, H. (2012a) Chitinase production and antifungal potential of endophytic Streptomyces strain P4. Maejo International Journal of Science and Technolnology 6:95-104.

19. Hsu, S. C. and Lockwood, J. L., 1975. Powdered chitin agar as a selective medium for enumeration of actinomycetes in water and soil. Journal of Applied Microbiology. 29:422-26.

20. Green, F., Clausen, C.A. and Highley, T.L. (1989) Adaptation of the Nelson-Somogyi reducing-sugar assay to a microassay using microtiter plate. Annals of Biochemistry 12:197-99.

21. Gangwar M, Khushboo, Saini1 P (2014) Diversity of endophytic actinomycetes in Musa acuminata and their plant growth promoting activity. Journal of Biological and Chemical Sciences 1(1):13-23

22. Khushboo, Kaur N (2019) Screening of Endophytic Actinomycetes for their Plant Growth Promoting Activity and for Biocontrol in Chilli (Capsicum annum) against Sclerotium Rolfsii. International Journal of Science and Research 8(8): 1683-1690

23. Bhosale . H.J. and Kadam T.A. (2015) Generic diversity and a comparative account on plant growth promoting characterstics of actinomycetes in roots and rizosphere of Saccharum officinarum. International journal of Current Microbiology and Applied Science 4(1):230-244.

24. Young,M.E. and Bell, R.L.(1985) Kinetics of chitinase production.II Relationship between bacterial growth, chitin hydrolysis and enzyme synthesis. Journal of Biotechnology 21:679-82.

25. Neugebour, E., Gamache, B., Dery, C. and Brzezinski, R., 1991. Chitinolytic properties of Streptomyces lividans. Archieves of Microbiology 156: 192-97.

26. Passari, A. K., Mishra, V. K., Gupta, V. K., Yadav, M. K. and Saikia, R. (2015) In vitro and in vivo plant growth promoting activities and DNA fingerprinting of antagonistic endophytic actinomycetes associates with medicinal plants. PLoS One 10(9): e0139468.

27. Rawlinson, L. B., Ryan, S. M., Mantovani, G., Syrett, J. A., Haddleton, D. M. and Brayden, D. J., 2010. Antibacterial effects of poly (2-(dimethylamino ethyl) methacrylate) against selected Gram-positive and Gramnegative bacteria. Biomacromolecules 11: 443-453. 